University for Business and Technology in Kosovo

UBT Knowledge Center

Nov 2nd, 2:00 PM - 2:15 PM

\title{
Special Proceedings As An Expression Of The Will Of The Parties In The Albanian Penal Procedural System
}

Gerti Tartale

Mustafa Matohiti, gerti_j@yahoo.it

Follow this and additional works at: https://knowledgecenter.ubt-uni.net/conference

Part of the Law Commons

\section{Recommended Citation}

Tartale, Gerti, "Special Proceedings As An Expression Of The Will Of The Parties In The Albanian Penal Procedural System" (2013). UBT International Conference. 46.

https://knowledgecenter.ubt-uni.net/conference/2013/all-events/46

This Event is brought to you for free and open access by the Publication and Journals at UBT Knowledge Center. It has been accepted for inclusion in UBT International Conference by an authorized administrator of UBT Knowledge Center. For more information, please contact knowledge.center@ubt-uni.net. 


\title{
Special Proceedings As An Expression Of The Will Of The Parties In The Albanian Penal Procedural System
}

\author{
Gerti Tartale \\ Affiliation address: Rr. "Mustafa Matohiti” No. 14, Tirana \\ gerti_j@yahoo.it
}

\begin{abstract}
Special proceedings constitute the instrument with which the legis lator, through variants and articulations, pursues the goal of penal policy, moving from the diversity of procedural situations, the nature of the offenses, the simplicity of the estimations, and the manner of application of punishment. The legislator articulates the choice of different procedural ways. Special proceedings are provided in the Italian Code of Procedure of 1930. In Albania for the first time they are provided in the Penal Procedural Legislation of 1937 and later in the Codes of Penal Procedure of 1979, 1981, 1983, 1995, and on wards. Not without significant differences regarding the actual ones, expanding over time, above all in relation to the time of the request, of the parties who have the right to demand it and of the bodies who have the right of decision, they have evolved. The uniqueness of these special procedures is seen in the plan of judicial economy.
\end{abstract}

\section{Failure or dismissal of the criminal case}

"Direct Trial" and "Judgment by Criminal Decree" as proceedings have specific dates in 1937 during the period of the Kingdom of Albania ${ }^{*}$. According to the requests of Chapter III (Article 13) crimes and misdemeanors, in which the applicable provisions of this law, when they entered the primary juris diction of the Court. So these kind of special considerations apply to criminal offenses and offenses under the jurisdiction of this court. These trials were procedures that shorten the first time from the occurrence of the act in its immediate judgment, and punishment when the defendant was guilty or not guilty when he was innocent, or there was a criminal offense. Judgment by decree of further shorten the time from the occurrence of the offense and the decision to award, after preliminary investigation and trial avoided a hearing to review the evidence in judicial debate between accuser and accused parties.

\subsection{Failure or dismissal of the criminal case}

"Failure of the criminal case" is provided as an institute of law, from the legislator in Article 73 of the Penal Code, approved by Law Nr. 6069, date on 25.12.1979 and amended by Law no. 6300 dated on 03.27.1981, the Law nr.6801, dated on 29.06.1983. In this criminal procedural provision, namely section of 73/1 of the Criminal Procedure Code the legis lator predicted that: "The Court, a single judge or investigator, in certain cases, have the right not to start criminal case, or during the investigation and trial in the first instance, to stop it, when appreciate the gravity of the offense committed and the person is small and when it shows deep remorse. In these cases, failure to begin or termination of the criminal case can also be made at the request of state organs, social organizations and workers collectives *. Referring to this provision of criminal - procedure, it is clear that we are before a type examination procedure and the decision of a particular body of preliminary investigation, the judge and the court at that time, so a separate trial. By adopting the implement of this provision, the legislator has had to develop a political criminal proceeding and save people that randomly were inserted into the path of committing crimes from criminal punishment, people who will not repeat them in the future. The implementation of this procedural - criminal provision, provided from Article 73 of the Criminal Procedure Code, can be used: a) the criminal case has not started that is right only of the investigator and the judge; b) the criminal case is started and is under investigation or trial. From its analys is we will analyze the subjects that have the legal right to decide not to begin the case, or to dismiss it. These subjects are: the court, a single judge, and an investigator. While initiation of this 
decision which will be taken to a certain person, the right to request has: the court, the court, a single judge or investigator, to implement this procedural requirement of criminal - law, but not even the accused, as a party to the

process. The initiation of the criminal proceeding was special jurisdiction of the court, of the judge and of the bodies of preliminary investigation, provided it, as an exception to the general rule on matters investigated and sent to court, the charges by the prosecutor.

The investigator initially had the right not beginning or the termination of the criminal case on its own initiative, for the offense of his competence, or the returned case when difficulties facing court for investigation, when met the conditions set out in this procedural Criminal-provision, decisions which if were taken contrary to the requirements of law, they were complete with protest, as a reaction to its illegality ascertained of a body established by the investigation, to the head of the district investigation body or the Head of General Investigation*. The Court, in the event that if noticed that the investigation authorities sending a case to trial, had applied unfairly not starting or dismissal of the criminal case, she annulled that decision and continue the criminal proceeding. According to the procedures provided for that individual, who had fraudulently obtaining benefits provided by law from the application of this criminal - procedural provision. For example, on denunciation of the victim H.Gj., on 14/02/1987 had started the criminal proceedings for willful injury, offense provided by Article 93/1 of 13 of the Criminal Code*, against two defendants M.R. and A.E., because both of themhas blocked his road. The defendant A.E., has shot in the face with chain and the other with another tool, but this has not affected the victim. The investigation, upon having execute some actions have ceased the case against they, bas ed on Article 73 of Penal Procedure Code*, citing that there are all conditions required by this provision, as the deep regret of the defendant, small gravity of the offense and of the author. On the complaint of the injured H.L., the head of the investigative body took into consideration the decision of dismissing the criminal case and found that the decision taken was unfounded, because it was not considered as a lack ofdeep regret to defendant, neither the gravity of the offense and the author, who had previous criminal background. Therefore, the director of the preliminary investigation body annulled the decision of dismissal of the criminal case and ordered a preliminary investigation body of the district to reinvestigate it*. By a decree of the Presidium of the National Assembly, to Article 73 of Penal Procedure Code (after the third paragraph) was added a power to the prosecutor taken decisions: "The investigator's decision is implemented after the prior approval of the prosecutor. The decision is sent to the body that has conducted the denunciation ${ }^{*}$. With this change of law, the decisions of the preliminary investigation had not produced any executive powers and the consequences were obtained by the investigator, but produce their effects only when these decisions were approved by the prosecutor. The judge had the right not to start a criminal case, or to dismiss it, when there are issues that followed the complaint of the injured accuser, or those deemed directly. The judge took this decision will only hearing, as when the issues are those of his competence, but also for those who have come from the body of the preliminary investigation and he has spent the decision to be reviewed in hearing court. In this session would be decided whether to apply this legal provision, when conclude that the final decision would be taken by a single judge, in reviewing acts of the fulfilled the criteria provided by law. The Court of First Instance was right to dismiss any criminal case, both initiated and sent to trial by judge alone, as well as those who came from the investigative bodies set up charge of investigating the evidence presented before it, the folder listed in the preliminary investigation, the research met under article 73 of the Criminal Procedure Code, taking this decision at the hearing. The Court of First Instance can apply this procedural provision - even when the criminal case is overruled by the Court of Second Instance and returned to new inquiry or new trial, necessarily in hearing session, when the criteria stipulated by Article 73 of the Penal Code*, although the latter does not have this right. Of course, here excluded individual's request to seek application for not beginning or termination of the criminal case at his request, because the political system and, therefore, the procedural criminal - system, who was inquisitor type specific of that time, where the accused did not enjoy their rights as equal parties in the criminal process. This special type of proceeding was conducted, for judicial economy after the preliminary investigation or adjudication avoid and not engage organs for criminal charges criminal proceedings or criminal proceedings initiated as preliminary investigation in court. Referring to the optional right provided by law, under which the initiation of this proceeding may require special and state bodies, social organizations and worker collectives, this definition had also given an opportunity in the workplace communities, living or social life that makes a particular 
person, when committing a criminal offense. In this framework has been provided that, prior to receipt of the decision of not initiating or holiday, retired community opinion, then the center of the collective work or residence, but this requirement was not binding, was on the faculty of the body of criminal proceedings. This was aimed at obtaining more objective decisions of the organs of criminal proceedings, as well as avoids unilateral decisions of bodies of preliminary investigation, the only court judge. The collective opinion of the work etc.., obviously sent written and directed authoritie s to criminal proceedings, in order to have them in the final evaluation will be made for the position that will be held against a subject who had committed a criminal offense, but in order to meet the requirements of the law for not initiating application or termination of criminal proceedings under section 73 searches the Code of Criminal Procedure, receive, and have the community opinion. When this opinion was based in law and in fact met the requests of Article 73 of Criminal Procedure Code, the authorities of criminal proceedings, the court, a single judge and investigator, took the decision in conformity with the criminal procedural law, for a person who had committed a criminal offense, but that which was required by the state or social organizations in writing, not to commence or dismiss criminal proceeding against him. To apply this procedural provision, the law required: a) the small dangerousness of the offense committed, b) small dangerousness of the pers on (the subject of a criminal offense), c) deep repentance of the person (the subject of a criminal offense), d) replacement of the damage caused by the offenses.

The complaint of the injured party, provided in the fourth paragraph of Article 73 of the Criminal Procedure Code for criminal offense on appeal, the case has begun on the request of the victim in front of the court*, at first view seems a guarantee for the injured party, but in fact is a formal guarantee. The body of procedure, taking unfairly the availability right for starting the criminal proceedings or the dismissal on it will, and placing the judgment of the procedure body, has actually done the decision taken, supposedly gives right to appeal in court, when this right cannot be exercised by these bodies, and the processing of the complaint of the injured party would set in procedures, when it was not taken no thought for the decisions taken. So this right provided on this provision is in contravention of the determination by the legislature referred to the Article 73/4 of Criminal Procedural Code and Article $63 / 3 / 5$ of Criminal Procedure Code and, as such, does not guarantee to the injured party for the charges he had field in criminal proceedings bodies, which is administered by the criminal proceedings body, in terms of not starting or termination of the criminal case, on the initiative of the procedure bodies or state organs, social organizations or worker collectives.

The prosecutor protest against the decision of not starting or dismiss a criminal case, it is clear fromthe provisions made by legislators in Article 73/4 of Criminal Procedure Code. The prosecutor was supported on the right to provide criminal and procedural law and of section 39 Criminal Procedure Code, which stipulated that: "The protest is the act by which the prosecutor requires the annulment or the changing of court decisions and of the investigation decisions of other illegal acts. With the presentation of the protest the enforcement of the decisions is suspended till its review. The protests against the decisions of the investigation can be done at any time". So, the objects of protest are all decisions made by the investigator or the group of investigators, without exception, when their content is in violation of the law. The prosecutor, along with protest, attaches the verification materials, the analysis of which had reached the conclusion that in a particular case with a decision was violated procedural criminal law. Within 10 days of protests reviewed by the head of the investigation and the decision was taken to restore the legitimacy on the investigation that was not respected by the investigator with the protest decision*. To the prosecutor, with the subsequent changes were entitled to a copy of the decision taken in implementation of this procedural provision, should be sent by the court, by a single judge and by the investigator, who as an implementation of control of legality of that time, have opportunity to check the legality of these decisions, of the investigation, of the court and of the single judge, in application of procedural criminal - law. When ascertained the failure of the law in these decisions, to oppose them with the response means within legal time.

The bodies that have fill denunciations, referring to Article 73 of Criminal Procedure Code Law no. 801, dated on 29.06.1983, to which was added a paragraph was provided that: "The Court, a single judge and the investigator, sent to the prosecutor and to the investigative body that have fill the denunciation , a copy of the decision of dismissal or the initiation of the criminal case" $\mathrm{e}^{*}$, were right, beside the prosecutor, to complain the decision, when they had conduct the denunciation to the investigation bodies or prosecution. As they had the right to gain more aware of the start of criminal proceedings, even after 
the informing of the decision of the dismissal or to not start taken from the bodies of criminal proceedings under the law provision, can make a complain when disagreed with the court decision, the single judge decision or the body of preliminary investigation decision, to start or to dismiss the case, pursuant to the requests of section 73 of Criminal Procedure Code.

With the changes in legislation, only the court decides to accept or not the request submitted by the parties, to any required special trial, when she persuaded on the merits of the claim, which is associated with the completion of the requirements that provides the Criminal Procedure Code. Of course, it decides to the hearing, after hearing the prosecutor, the representative of the accused, when he has one, or in his absence, the defense with power of attorney to represent him in absentia, to request the direct trial or accelerated procedure, or the injured accuser, the plaintiff and the defendant. So, in contrast to earlier predictions of legis lation, the Criminal Procedure Code in force, and the defendant has the right to submit to the court a request for application of the special trial court, which had never before in his rights, in the criminal proceeding against him, on public or private charges. The Court, after considering the requests, if accepts the requirements provided for in the provisions of Chapter IV of Criminal Procedure Code, the reviews and, if they accept, implements the procedures provided for direct judgment of the trial development, considering the evidence at the hearing. At the short judgment, for which the session to debate the evidence is overcome for the pers on who committed the crime, expresses as a rule for accepting the request, passing the hearing to listen to the conclusions of the prosecutor, of the defendant, of the defense, civil plaintiffs and defendants, and in case of non - rejected the request and the trial continued with the ordinary trial procedures.

At sentencing, the court shall be guided by the provisions of the Criminal Code*, as well as the provisions of the Criminal Procedure Code*, which should take into account as a mitigating circumstance, among others, the repentance, replacing the damage caused by the offense, when relationship between the pers on who committed the crime and the victim are normalized etc... Whereas, when accepted accelerated procedure, for the punishment the court will also consider reducing the sentence of imprisonment on $1 / 3$ of it, or a fine, or substitute life imprisonment with twenty - five years of imprisonment. So, unlike the former Criminal Procedure Code, is only the court's exclusive juris diction, the application of such favorable decision on the best favorable and mitigating of a person prosecuted when found circumstances under Articles 48 and 49 of the Criminal Code, because regardless of the circumstances mentioned in Article 48 of the Criminal Code, the court may also consider other circumstances as may be, good personality, family situation with many children, etc.., as long as it is called as such to justify facilitating the sentence.

In Article 52 of the Criminal Code stipulates "Excluding the minors from the punishment". The court, considering the three essential elements, which are: The low volatility of the offense, The concrete circumstances of its commission, The previous behavior of juvenile may exclude him from the punishment, to decide whether or not the minor in an educational institution. Even this right the court has to do with that, she makes a juvenile proceeding politics of punishment even softer exempt them from punishment and sent to an educational institution. The outcome of this application will bring the minors to be educated, to return to family life, to integrate into society, to escape once and for all from the clutches of elements culprit. These special legal proceedings have made its contribution in preventing crime, but in the future should go further. Must be improved their applications to problems arising in judicial practice. Must be provided in the Criminal Procedure Code, special proceedings in provided from modern legal systems Anglo - American, as is the plea agreement (Plea Bargaining). The application of this special proceeding has grown and is mainly achieved in the context of the plea agreement*, in these legal systems where applicable in the vast majority of criminal proceedings initiated, for the effectiveness that give velocity of solving the is sue and prevent crime effectively.

\section{References}

1. Albanian Criminal Code, Tirana 1927

2. Official Journal, Tirana 05/19/1937

3. Code of Criminal Procedure of the People's Socialist Republic of Albania, as amended by Law no. 801 , dated 29.06.1983

4. Criminal Code of the People's Socialist Republic of Albania, Tirana 1983 
5. Archive of the Presidium of the National Assembly

6. Criminal Code of the People's Socialist Republic of Albania, Tirana 1988

7. Criminal Code of the People's Socialist Republic of Albania, Tirana 1982

8. Criminal Procedural Law, Special Part, Tirana 1988

9. Archives of General Prosecutor, Tirana 1988

10. Criminal Procedure of the People's Socialist Republic of Albania, Tirana 1988

11. Organization of justice in the People's Socialist Republic of Albania, Investigation, Tirana 1988

12. Criminal Procedure, group of authors, Tirana 2010

13. Code of Criminal Procedure of the Republic of Albania in force, Chapter IV

14. Criminal Code of the Republic of Albania in force

15. The jurisprudence of the Court of First Instance and the Court of Appeals in Tirana

16. John Langhem, Comparative Criminal Procedure, Germany 1997 